\title{
Influencing chondrogenic differentiation of human mesenchymal stromal cells in scaffolds displaying a structural gradient in pore size
}

Citation for published version (APA):

Di Luca, A., Szlazak, K., Lorenzo-Moldero, I., Ghebes, C. A., Lepedda, A., Swieszkowski, W., Van Blitterswijk, C., \& Moroni, L. (2016). Influencing chondrogenic differentiation of human mesenchymal stromal cells in scaffolds displaying a structural gradient in pore size. Acta Biomaterialia, 36, 210-219. https://doi.org/10.1016/j.actbio.2016.03.014

Document status and date:

Published: 01/05/2016

DOI:

10.1016/j.actbio.2016.03.014

Document Version:

Publisher's PDF, also known as Version of record

Document license:

Taverne

Please check the document version of this publication:

- A submitted manuscript is the version of the article upon submission and before peer-review. There can be important differences between the submitted version and the official published version of record.

People interested in the research are advised to contact the author for the final version of the publication, or visit the DOI to the publisher's website.

- The final author version and the galley proof are versions of the publication after peer review.

- The final published version features the final layout of the paper including the volume, issue and page numbers.

Link to publication

\footnotetext{
General rights rights.

- You may freely distribute the URL identifying the publication in the public portal. please follow below link for the End User Agreement:

www.umlib.nl/taverne-license

Take down policy

If you believe that this document breaches copyright please contact us at:

repository@maastrichtuniversity.nl

providing details and we will investigate your claim.
}

Copyright and moral rights for the publications made accessible in the public portal are retained by the authors and/or other copyright owners and it is a condition of accessing publications that users recognise and abide by the legal requirements associated with these

- Users may download and print one copy of any publication from the public portal for the purpose of private study or research.

- You may not further distribute the material or use it for any profit-making activity or commercial gain

If the publication is distributed under the terms of Article $25 \mathrm{fa}$ of the Dutch Copyright Act, indicated by the "Taverne" license above, 
Full length article

\title{
Influencing chondrogenic differentiation of human mesenchymal stromal cells in scaffolds displaying a structural gradient in pore size
}

\author{
Andrea Di Luca ${ }^{\mathrm{a}}$, Karol Szlazak ${ }^{\mathrm{b}}$, Ivan Lorenzo-Moldero ${ }^{\mathrm{a}, \mathrm{d}}$, Corina A. Ghebes ${ }^{\mathrm{c}}$, Antonio Lepedda ${ }^{\mathrm{e}}$, \\ Wojcech Swieszkowski ${ }^{\mathrm{b}}$, Clemens Van Blitterswijk ${ }^{\mathrm{a}, \mathrm{d}}$, Lorenzo Moroni ${ }^{\mathrm{a}, \mathrm{d}, *}$ \\ ${ }^{a}$ University of Twente, Tissue Regeneration Department, Drienerlolaan 5, 7522 NB Enschede, The Netherlands \\ ${ }^{\mathrm{b}}$ Materials Design Division, Faculty of Material Science and Engineering, Warsaw University of Technology, 141 Woloska Street, 02-507 Warsaw, Poland \\ ${ }^{\mathrm{C}}$ University of Twente, Developmental Bio-engineering Department, Drienerlolaan 5, 7522 NB Enschede, The Netherlands \\ ${ }^{\mathrm{d}}$ Maastricht University, MERLN Institute for Technology Inspired Regenerative Medicine, Complex Tissue Regeneration Department, P. Debyelaan 25, 6229 HX Maastricht, \\ The Netherlands \\ ' Universita'di Sassari, Department of Biomedical Sciences, Via Muroni 25, Sassari, Italy
}

\section{A R T I C L E I N F O}

\section{Article history:}

Received 22 October 2015

Received in revised form 29 February 2016

Accepted 7 March 2016

Available online 8 March 2016

\section{Keywords:}

Gradients

3D scaffolds

Additive manufacturing

Stem cells

\begin{abstract}
A B S T R A C T
Articular cartilage lesions have a limited ability to heal by themselves. Yet, golden standard treatments for cartilage repair such as drilling, microfracture and mosaicplasty provide further damage and an unstable solution that degenerates into fibrocartilage in time. Articular cartilage presents a number of gradients in cell number and size along with structural gradients in extra cellular matrix (ECM) composition. Therefore, creating scaffolds that display a structural gradient can be an appealing strategy for cartilage tissue regeneration treatments. In the present study, a scaffold with an in-built discrete gradient in pore size was produced by additive manufacturing. Human mesenchymal stromal cells (hMSCs) were seeded within the gradient scaffolds and their proliferation, differentiation and ECM deposition was evaluated with respect to 2 non-gradient scaffolds. Glycosaminoglycan (GAG) deposition was significantly higher in gradient scaffolds and non-gradient scaffolds with the smallest pore size compared to non-gradient scaffolds with the largest pore size. A gradual increase of chondrogenic markers was observed within the gradient structures with decreasing pore size, which was also accompanied by an increasingly compact ECM formation. Therefore, scaffolds displaying a structural gradient in pore size seem to be a promising strategy to aid in the process of hMSC chondrogenic differentiation and could be considered for improved cartilage tissue regeneration applications.
\end{abstract}

\section{Statement of Significance}

We present the development of a novel hierarchical scaffold obtained by additive manufacturing Structural hierarchy is obtained by changing pore size within the pore network characterizing the fabricated scaffolds and proves to be a functional element in the scaffold to influence adult stem cell differentiation in the chondrogenic lineage. Specifically, in regions of the scaffolds presenting smaller pores an increasing differentiation of stem cells toward the chondrogenic differentiation is displayed. Taking inspiration from the zonal organization of articular cartilage tissue, pore size gradients could, therefore, be considered as a new and important element in designing 3D scaffolds for regenerative medicine applications, in particular for all those tissues where gradient physical properties are present.

(C) 2016 Acta Materialia Inc. Published by Elsevier Ltd. All rights reserved.

\section{Introduction}

Cartilage is the tissue located at the extremity of long bones and is responsible for the transmission of forces from the articular

\footnotetext{
* Corresponding author at: Maastricht University, Complex Tissue Regeneration Department, Universiteitsingel 40, 6229 ER, The Netherlands.

E-mail address: l.moroni@maastrichtuniversity.nl (L. Moroni).
}

surface to the underlying subchondral bone [1]. Cartilage can be affected by progressive degenerative diseases such as osteoarthritis, which involves the osteochondral or chondral tissue depending on the depth of the injury. This process can be triggered by a severe trauma, repetitive minor injuries or aging process [2]. Currently, an optimum treatment for such type of lesions is still under debate. Articular cartilage lesions generally do not heal, or heal only partially under certain biological conditions [3]. Among the available 
treatments, most of them are based on the disruption of the damaged site such as drilling, microfracture or spongialization [4,5]. Bleeding from the subchondral bone would then ensure the delivery of mononuclear cells and growth factors contained in the bone marrow responsible for the temporary healing of the damaged site. Other proposed techniques consist in the transplantation of autologous cells [6,7], perichondrial/periosteal grafts [8], and autologous or allogenic osteochondral transplantation $[9,10]$. Since all these proposed solutions present several drawbacks related to morbidity, risks of infections, lack of available tissues, and redegeneration of the repaired tissue, the use of biomaterial-based strategies to promote and direct tissue growth emerged in the past decades. Several techniques have been proposed in literature to produce scaffolds, such as freeze drying [11], salt leaching $[12,13]$, solvent casting [13] and gas foaming [14]. The success of a scaffold resides in some characteristic features such as total porosity, pore size and interconnectivity, mechanical and physico-chemical properties. The fore mentioned techniques lack control of one or more of these characteristics. Additive manufacturing has been used to fabricate scaffolds due to its ability of overcoming these drawbacks and the possibility to fine tune scaffolds characteristics such as pore shape and size. Additionally, a gradual variation of the scaffolds characteristics can be achieved within the same construct, allowing the design and production of scaffolds displaying structural gradients $[15,16]$.

Gradients are also present in the human body from the developmental phase to adult life. Morphogen gradients are known to lead to the formation of the osteochondral tissue [17]. At the tissue interface, the gradual variation from one tissue to the other is based on gradients. Skin and bone present a gradient structure in the axial direction and the radial direction, respectively. Cartilage is a tissue which displays an internal variation of properties such as stiffness [18-20], extracellular matrix (ECM) composition $[2,18]$ and cell shape and number $[21,22]$ along the axial direction as well. In particular, articular cartilage displays a gradient in proteoglycans, collagen type II, and water content. While proteoglycan content increases from the calcified region to the surface plateau, collagen type II and water content increases from the surface plateau to the calcified zone [23]. Therefore, the use of gradient scaffolds could be a feasible solution for cartilage regeneration. In the present study, scaffolds with a discrete gradient in pore size in the axial direction were fabricated by additive manufacturing. The proliferation, ECM deposition and differentiation of human bone marrow derived mesenchymal stromal cells (hMSCs) toward the chondrogenic lineage were evaluated. Furthermore, we analyzed the differentiation of hMSCs within the compartments of the gradient in order to correlate their differentiation to the size of the pores. We hypothesized that a variation in pore size could indirectly result into a local gradient in nutrient availability during culture. Correspondently, this may result in gradual hypoxic culture conditions, which are known to facilitate chondrogenesis [24,25]. hMSCs have been chosen due to their potential to differentiate into different skeletal lineages, among others [26,27]. Their presence in the mononuclear cell fraction of the subchondral bone marrow further guarantees a potentially straightforward clinical application, as hMSCs are often thought to be responsible for cartilage repair in current clinical surgical procedures such as microfracture.

\section{Materials \& methods}

\subsection{Scaffolds preparation}

Scaffolds were fabricated via 3D fiber deposition (Bioscaffolder, SysENG, Germany). Scaffolds made of poly(ethylene oxide terephthalate)/poly(butylene terephthalate) (PEOT/PBT) were produced.
PEOT/PBT is a family of block co-polymers characterized by an $a$ PEOT $b$ PBT $c$ nomenclature, where $a$ is the molecular weight of the starting PEG block and $b$ and $c$ are the PEOT/PBT ratio. A 300PEOT55PBT45 composition was chosen due to its proven potential for skeletal regeneration [28,29]. Briefly, the polymer (300PEOT55PBT45, PolyVation, The Netherlands) was placed in a stainless syringe and processed at $200^{\circ} \mathrm{C}$. The molten polymer was extruded through a cartridge unit, by the application of a nitrogen flow with a pressure of 5 bar from a pressurized cap and an extrusion screw rotation of $200 \mathrm{rpm}$.

During plotting, the needle diameter, layer thickness and speed were kept constant at $200 \mu \mathrm{m}, 150 \mu \mathrm{m}$ and $180 \mathrm{~mm} / \mathrm{min}$, respectively. The fiber spacing was kept constant to $500 \mu \mathrm{m}$ and $1100 \mu \mathrm{m}$ for non-gradient (NG) scaffolds and varied from $500 \mu \mathrm{m}$ to $1100 \mu \mathrm{m}$ for gradient $(G)$ scaffolds. The fiber spacing was changed every millimeter. The scaffolds were plotted in blocks of $20 \times 20 \mathrm{~mm}$ and $4 \mathrm{~mm}$ in height. The tested samples were $4 \times 4 \mathrm{~mm}$ cylinders punched out from the blocks.

\subsection{Cell expansion and culture}

hMSCs (male, age 22) were retrieved from the Institute of Regenerative Medicine (Temple, Texas). Briefly, a bone marrow aspirate was drawn and mononuclear cells were separated using density centrifugation. The cells were plated to obtain adherent hMSCs, which were harvested when cells reached $60-80 \%$ confluence. These were considered passage 0 (P0) cells. These P0 cells were expanded, harvested and frozen at passage 1 (P1) for distribution. Cells were grown in MSC proliferation medium, which contains minimal essential medium ( $\alpha$-MEM, Life Technologies, Bleiswijk, the Netherlands) supplemented with $10 \%$ fetal bovine serum (FBS, Lonza), $100 \mathrm{U} / \mathrm{ml}$ penicillin (Life Technologies, Bleiswijk, the Netherlands), $10 \mu \mathrm{g} / \mathrm{ml}$ streptomycin (Life Technologies, Bleiswijk, the Netherlands), $2 \mathrm{mM}$ L-glutamin (Life Technologies, Bleiswijk, the Netherlands), $0.2 \mathrm{mM}$ L-ascorbic acid 2-phosphate magnesium salt (ASAp, Sigma-Aldrich, Zwijndrecht, The Netherlands) and $1 \mathrm{ng} / \mathrm{ml}$ of basic fibroblast growth factor-2 (bFGF-2, Fisher Scientific, Landsmeer, the Netherlands) at $37{ }^{\circ} \mathrm{C}$ in a humid atmosphere with $5 \% \mathrm{CO}_{2}$. Cells were expanded up to approximately $80 \%$ confluency and either frozen for further use or seeded on the scaffolds.

\subsection{Cell seeding on scaffolds}

After trypsinization with $0.25 \%$ trypsin (Life Technologies, Bleiswijk, the Netherlands), cells (passage 2-4) were counted using a Bückner chamber and re-suspended in proliferation medium at a density of 500,000 cells in $40 \mu \mathrm{L}$. The day before seeding, scaffolds were disinfected in 70\% EtOH for 30 min under stirring, washed 3 times in phosphate buffered saline solution (PBS) (Lonza, Breda, the Netherlands), and incubated overnight in proliferation medium to allow protein adsorption on the scaffold's fibers. After protein adsorption, the $40 \mu \mathrm{L}$ of cell suspension were placed on the scaffold in a drop wise fashion to account for a cell seeding density of 500,000 cells/scaffold. The seeded scaffolds were placed for $4 \mathrm{~h}$ in the incubator to allow cell adhesion before adding the cell culture medium.

Cells were cultured on the G and NG scaffolds for 7 days in proliferation medium. At day 7, the proliferation medium was changed and the cell-seeded scaffolds were cultured for another 28 days in basic medium presenting the same formulation as the proliferation medium without bFGF, or chondrogenic medium consisting of DMEM supplemented with $50 \mathrm{mg} / \mathrm{mL}$ ITS-premix (Bexton Dickinson), $0.4 \mathrm{mM}$ Proline (Sigma-Aldrich, Zwijndrecht, The Netherlands), $50 \mathrm{mg} / \mathrm{mL}$ ascorbic acid (ASAp, Sigma-Aldrich, Zwijndrecht, The Netherlands), $100 \mathrm{mg} / \mathrm{mL}$ sodium pyruvate 
(Sigma-Aldrich, Zwijndrecht, The Netherlands), $100 \mathrm{U} / \mathrm{ml}$ penicillin (Life Technologies, Bleiswijk, the Netherlands), $10 \mu \mathrm{g} / \mathrm{ml}$ streptomycin (Life Technologies, Bleiswijk, the Netherlands), $10 \mathrm{ng} / \mathrm{mL}$ transforming growth factor $\beta 3$ (TGF- $\beta 3$ ) (Life Technologies, Bleiswijk, the Netherlands) and $10^{-7} \mathrm{M}$ dexamethasone (SigmaAldrich, Zwijndrecht, The Netherlands). Scaffolds were flipped every day so to exchange "bottom" and "top" side of the scaffolds to take into account the possible effect of gravity on cell distribution, where the "top" side is considered as the one with the smaller pore size in the gradient scaffolds.

\subsection{Partition analysis}

To see the differences within the hMSCs cultured in the different area of the gradient scaffolds, after 14 and 28 days under differentiation conditions, the constructs were collected, washed 3 times with PBS and cut in 3 portions of $1 \mathrm{~mm}$ in height. The division of the pore size formed with a fiber spacing of $900 \mu \mathrm{m}$ with the pore size formed with a fiber spacing of $1100 \mu \mathrm{m}$ was not possible due to the poor mechanical properties; therefore, the 2 pore size portions were analyzed together. Biochemical studies and gene expression analysis were performed to the full and partitioned scaffolds.

\subsection{Biochemical study}

\subsubsection{DNA analysis}

The cell number per scaffold was calculated from the $\mu \mathrm{g}$ of DNA, obtained by a Cyquant DNA assay kit (Life Technologies, Bleiswijk, The Netherlands). Briefly, each scaffold was cut to improve lysis efficiency and freeze-thawed 5 times. After the freeze-thawing process, cells within the scaffolds were lysated by diluting the $20 \times$ lysis buffer provided with the kit using a saline buffer (180 mM NaCl, $1 \mathrm{mM}$ EDTA in distilled water). After $1 \mathrm{~h}$ of lysis, samples were sonicated 2 times for $10 \mathrm{~s}$ using a Branson sonifier 250 (Emerson Industrial Automation, USA). DNA content was quantified with a CyQuant kit (Life Technologies, Bleiswijk, the Netherlands) according to manufacturer's protocol and fluorescence was measured at $480 \mathrm{~nm}$ using a spectrophotometer LS50B (Perkin Elmer, The Netherlands). DNA concentrations were calculated from a $\lambda$ DNA standard curve.

\subsubsection{GAG amount}

To evaluate the differentiation toward the chondrogenic lineage, the GAG amount was quantified using 1,9-Dimethyl Methylene Blue (DMMB) assay. Therefore, $25 \mu \mathrm{L}$ of sample were placed into a transparent flat bottom 96 well plate and $5 \mu \mathrm{L}$ of $2.3 \mathrm{M} \mathrm{NaCl}$ solution were added, then $150 \mu \mathrm{L}$ of DMMB solution were added and absorbance was read using a Multiscan Go (Fisher Scientific, Landsmeer, the Netherlands) plate reader at a wavelength of $525 \mathrm{~nm}$. GAG content was quantified with a chondroitin standard curve and corrected for DNA content.

\subsubsection{Western Blot Analysis}

hMSCs passage $2-4$ were cultured in normoxic ( $21 \%$ oxygen) conditions on both petri dishes and 3D scaffolds, and in hypoxic ( $2.5 \%$ oxygen) conditions on petri dishes only (positive control). The cells were lysed in radio-immunoprecipitation assay (RIPA) lysis buffer (sc-24948, SantaCruz Biotechnology). The protein content was determined using a Pierce BCA protein assay kit (\#23227, Thermo Scientific Pierce), with bovine serum albumin used as a standard. Each sample was mixed with $4 \times$ Laemmli Sample Buffer (\#161-0737, BioRad) under denaturing conditions. $20 \mu \mathrm{g}$ of protein sample were loaded per lane and resolved on a $4-20 \%$ precast polyacrylamide gel (\#456-8094, BioRad). Proteins were transferred to a PVDF membrane for immunoblotting. After blocking $1 \mathrm{~h}$ at room temperature with 5\% BSA in Tris-buffered saline containing 0.1\% Tween-20 (Santa Cruz Biotechnology), the membranes were incubated overnight at $4{ }^{\circ} \mathrm{C}$ with HIF-1 $\alpha$ (28b) antibody (\#sc-13515, Santa Cruz Biotechnology), or HIF-2 $\alpha$ antibody (\#sc-46691, Santa Cruz Biotechnology), diluted 1:250 in Tris-buffered saline containing $0.1 \%$ Tween-20). GAPDH antibody (\#sc-365062, Santa Cruz Biotechnologies) diluted 1:2500 was used as loading control for normalization. Membranes were washed with Tris-buffered saline, and incubated with horseradish peroxidase (HRP)-conjugated secondary antibodies (DAKO) diluted 1:2500 in Tris-buffered saline containing $0.1 \%$ Tween-20 for $45 \mathrm{~min}$ at room temperature. After washing, blots were developed using Clarity Western ECL Substrate (\#1705060, BioRad) and the HRP activity of the blots were imaged using a BioRad Chemidoc Touch imager. Finally, blots were semi-quantified using ImageJ.

\subsection{SEM analysis and computed tomography analysis}

G and NG scaffolds were analyzed by scanning electron microscopy (SEM, Philips - XL 30 ESEM-FEG). Directly after plotting, scaffolds were punched, cut in half, gold sputtered (Cressington sputter coater 108 auto) and analyzed. SEM images were analyzed using Image J software in order to measure the fiber diameter, fiber spacing, and pore dimensions. Pore dimensions can be calculated by subtracting the fiber dimension from the fiber spacing in the $\mathrm{x}-\mathrm{y}$ plane, while they are identical to the layer thickness in the $\mathrm{z}$ direction [30]. Scaffolds cultured in basic and chondrogenic media for 28 days were fixed using $10 \%$ formalin, dehydrated by an increasing series of ethanol concentration (50-60-70-80-90-96$100 \%$ ) and cut in half. The final dehydration step was carried out via immersion in Hexamethyldisilazane (Sigma-Aldrich, Zwijndrecht, The Netherlands) and overnight evaporation. Dry scaffolds were mounted on SEM stubs, gold sputtered, and analyzed for tissue formation. Directly after plotting, scaffolds were analyzed by micro-computed tomography $(\mu \mathrm{CT})$. The X-ray measurements were performed using SkyScan 1172 (Bruker) with the following working parameters of X-ray tube: $40 \mathrm{kV}$ and $250 \mu \mathrm{A}$. For a $3.97 \mu \mathrm{m}$ pixel size, 600 projections were taken with exposure time of $100 \mathrm{~ms}$ and 5 integrations for each exposition. The projections were reconstructed with the special software (NRecon, ver. 1.6.10.4, Bruker microCT) and then exported to CTAn (ver. 1.15.4.0+, Bruker microCT) for further 3D image analysis. Reconstructed slices were processed, resulting in 3D binary images. Object volume, available surface and fiber spacing were calculated for the whole volume of analyzed scaffolds.

\subsection{Gene expression analysis}

For gene expression analysis, the scaffolds were taken from the medium, washed twice with PBS, cut into small pieces, placed in an Eppendorf containing $750 \mu \mathrm{L}$ of TRIzol ${ }^{\circledR}$ (Invitrogen) and stored at $-80^{\circ} \mathrm{C}$. In case of partition analysis, the gradient scaffolds were cut in order to separate the gradient zones and the 3 samples were located in the same vial prior the addition of TRIzol ${ }^{\circledR}$, in order to ensure the collection of enough RNA. RNA isolation was performed by using a Bioke RNA II nucleospin RNA isolation kit (Bioke, Leiden, The Netherlands). $150 \mu \mathrm{L}$ of $\mathrm{CHCl}_{3}$ were added and the vials were vigorously mixed, followed by a centrifugation at $12,000 \mathrm{~g}$ for 15 min at $4{ }^{\circ} \mathrm{C}$. The aqueous phase was transferred into a new tube and an equal amount of $70 \%$ ethanol was added. The mixture was transferred into a filter column from the kit and the extraction was carried on following the manufacturer's protocol. RNA concentration and purity was evaluated via an ND1000 spectrophotometer (Nanodrop Technologies, USA); cDNA was synthetized using iScript $^{\mathrm{TM}}$ (BIO-RAD, Veenendaal, The Netherlands) according to the manufacturer's protocol. Quantitative polymerase chain 
reaction ( $\mathrm{qPCR}$ ) was performed on the obtained cDNA by using the iQ SYBR ${ }^{\circledR}$ Green Supermix (BIO-RAD, Veenendaal, The Netherlands) and the primers listed in Table 1 . PCR reaction was carried out on a MyiQ2 Two-Color Real-Time PCR Detection System (BIO-RAD, Veenendaal, The Netherlands) under the following conditions: the cDNA was denatured for $10 \mathrm{~min}$ at $95^{\circ} \mathrm{C}$, followed by 45 cycles, consisting of $15 \mathrm{~s}$ at $95^{\circ} \mathrm{C}, 15 \mathrm{~s}$ at $60^{\circ} \mathrm{C}$ and $15 \mathrm{~s}$ at $72^{\circ} \mathrm{C}$. A melting curve was generated from each reaction to test the presence of primer dimers and unspecific products. The cycle threshold was calculated by the Bio-Rad iQ5 optical system software, in which the threshold was set in the lower log-linear region of the fluorescent signal. Ct values were normalized by the B2M housekeeping gene and $\Delta \mathrm{Ct}$ ((average of $\mathrm{Ct}$ control) $-\mathrm{Ct}$ value). Results were expressed as fold induction in mRNA expression normalized to the gene expression of the gradient scaffolds cultured in basic medium. In the partition analysis, the relative RNA expression was normalized by the big pore region (900/1100) cultured under chondrogenic conditions.

\subsection{Statistical analysis}

All the quantitative data are expressed as mean \pm standard deviation. Statistics were performed using IBM SPSS Statistics 20. A two-way ANOVA with Tukey as post hoc test was used. Statistical significance between the control groups and the experimental groups is indicated with $\left(^{*}\right)$ which represents a p-value $<0.05,\left({ }^{* *}\right)$ which represents a p-value $<0.01$, and $\left({ }^{* * *}\right)$ which represents a p-value $<0.001$.

\section{Results}

\subsection{Scaffold characterization}

Four zones in the gradient scaffold can be distinguished (Fig. 1a and d), where the fiber spacing changed from bottom to top from $463 \mu \mathrm{m} \pm 17 \mu \mathrm{m}$, to $646 \mu \mathrm{m} \pm 9 \mu \mathrm{m}, 836 \mu \mathrm{m} \pm 23 \mu \mathrm{m}$, $1023 \mu \mathrm{m} \pm 26 \mu \mathrm{m}$. The resulting pore size was $326 \mu \mathrm{m} \pm 17 \mu \mathrm{m}$ when the fiber spacing was set at $500 \mu \mathrm{m}, 540 \mu \mathrm{m} \pm 11 \mu \mathrm{m}$ when the fiber spacing was set at $700 \mu \mathrm{m}, 744 \mu \mathrm{m} \pm 16 \mu \mathrm{m}$ and $968 \mu \mathrm{m} \pm 25 \mu \mathrm{m}$ when the fiber spacing was set at 900 and $1100 \mu \mathrm{m}$ respectively as analyzed from SEM. The fiber diameter was measured as $155 \pm 20 \mu \mathrm{m}$. The $\mu \mathrm{CT}$ analysis showed a pore size of $237.67 \mu \mathrm{m} \pm 7.77 \mu \mathrm{m}$ when the fiber spacing was set at $500 \mu \mathrm{m}, 389.33 \mu \mathrm{m} \pm 4.93 \mu \mathrm{m}$ with a fiber spacing of $700 \mu \mathrm{m}$, $509 \mu \mathrm{m} \pm 4.36 \mu \mathrm{m}$ and $538.33 \mu \mathrm{m} \pm 50.64 \mu \mathrm{m}$ when the fiber spacing was at $900 \mu \mathrm{m}$ and $1100 \mu \mathrm{m}$ respectively (Table 2b). Control scaffolds were plotted by keeping the fiber spacing constant at $500 \mu \mathrm{m}$ and $1100 \mu \mathrm{m}$, which was measured as $458 \mu \mathrm{m} \pm 15 \mu \mathrm{m}$ and $939 \mu \mathrm{m} \pm 88 \mu \mathrm{m}$, respectively, by SEM (Fig. 1c, and d). By increasing the fiber spacing, the volume of the pore in the different zones correspondently increased by $50 \%$ from the smallest to the largest pore size (Fig. 1f). In parallel, by increasing the pore size the surface available decreased from $114.75 \mathrm{~mm}^{2} \pm 11.34 \mathrm{~mm}^{2}$ in the smaller pore area to $44.72 \mathrm{~mm}^{2} \pm 14.16 \mathrm{~mm}^{2}$ in the largest pore area (Table $2 \mathrm{~b}$ ). The porosity of the different gradient areas increased from $55.1 \% \pm 1.4 \%$ to $81.8 \% \pm 0.8 \%$ (Fig. 1 e). The porosity

Table 1

List of primers used for the gene expression analysis of hMSCs differentiation toward the chondrogenic lineage.

\begin{tabular}{lll}
\hline Gene & Forward primer & Reverse primer \\
\hline B2M & ACAAAGTCACATGGTTCACA & GACTTGTCTTTCAGCAAGGA \\
Aggrecan & AGGCAGCGTGATCCTTACC & GGCCTCTCCAGTCTCATTCTC \\
Sox9 & TGGGCAAGCTCTGGAGACTTC & ATCCGGGTGGTCCTTCTTGTG \\
Collagen II $\alpha$ & CGTCCAGATGACCTTCCTACG & TGAGCAGGGCCTTCTTGAG \\
\hline
\end{tabular}

calculated with the $\mu \mathrm{CT}$ showed that the porosity of G scaffolds were close to the one of NG500 scaffolds, $69.52 \% \pm 0.31 \%$ and $70.80 \% \pm 0.06 \%$. NG1100 scaffolds displayed a porosity of $78.88 \% \pm 0.7 \%$ (Table $2 a$ ).

\subsection{Cell seeding efficiency and cell number}

The presence of the gradient as well as the different pore size of the controls didn't affect cell attachment at $8 \mathrm{~h}$ from seeding (Fig. 2a). At 28 days of differentiation, scaffolds cultured in basic conditions displayed a higher cell number compared to the ones cultured under chondrogenic conditions (Fig. 2b). Even at this late time point the porosity didn't affected the cell number per structure, since there was no statistical difference among gradient and non-gradient scaffolds.

\subsection{Induction of chondrogenic markers}

After 14 days under chondrogenic conditions 2 out of 3 markers chosen to detect chondrogenesis were upregulated (Fig. 3a). The early marker sox9 appeared highly upregulated with a 7-fold induction for the gradient and a 6- and 8-fold induction for the NG500 and NG1100, respectively. The late marker aggrecan was even more upregulated with a 38 -fold induction for the gradient, and a 32- and 31-fold induction for NG500 and NG1100 respectively. Collagen type II displayed an initial increase in its expression with an upregulation of 2-3 times fold. No major differences could be detected among the gradient and non-gradient structures. After 28 days under differentiation conditions the produced glycosaminoglycan (GAG) displayed a trend in which the NG1100 scaffolds showed $13.08 \pm 4.98 \mu \mathrm{g}$ of GAG/DNA, which was significantly lower than the amount of GAG deposited by NG500 scaffolds $(26.2 \pm 2.07 \mu \mathrm{g}$ of GAG/DNA) as shown in Fig. 3b. G scaffolds showed an amount of GAG/DNA of $21.39 \pm 2.92$, which was significantly higher with respect to the amount produced in NG1100 scaffolds.

\subsection{ECM analysis}

After 28 days, the constructs cultured in basic medium displayed cells adhering to the fibers with produced ECM bridging the pores and connecting subsequent fibers (Fig. 4a-f). When cultured under chondrogenic conditions, all the samples displayed the presence of ECM closing most of the pores (Fig. $4 \mathrm{~g}-1$ ). Samples cultured under chondrogenic conditions displayed a consistently higher ECM.

As shown in Fig. 4(m-p) from the small pores to the big pores throughout the entire pore network, the gradient scaffolds were filled with ECM. The ECM organization seemed more compact in the area with fiber spacing of $700 \mu \mathrm{m}$ and $500 \mu \mathrm{m}$ (Fig. 4n, o), and became looser when moving to the bottom part of the scaffolds characterized by the higher fiber spacing (Fig. 4p). Higher magnification showed in both G and NG scaffolds spread cell morphology, yet with more ECM fibrillary bundles present in $G$ scaffolds (Supporting Information, Fig. S2).

\section{5. hMSCs differentiation and ECM deposition in respect of the pore} size zone

\subsubsection{Gene expression per gradient zone}

As showed in Fig. 5, the expression of aggrecan, collagen type II and sox9 genes were analyzed in each portion of the gradient scaffolds. The early marker Sox 9 presented a 5-fold induction in the smallest pore region, significantly higher than in the biggest pore region. The portion with the fiber spacing of $700 \mu \mathrm{m}$ presented a 2-fold induction, similar to the largest pore region. Collagen type 
a

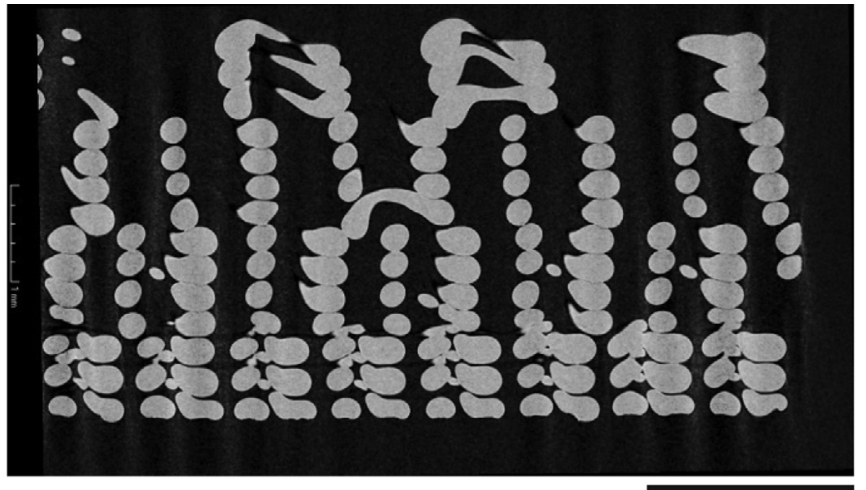

b

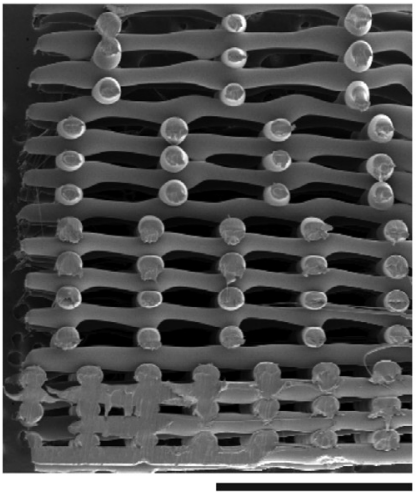

C

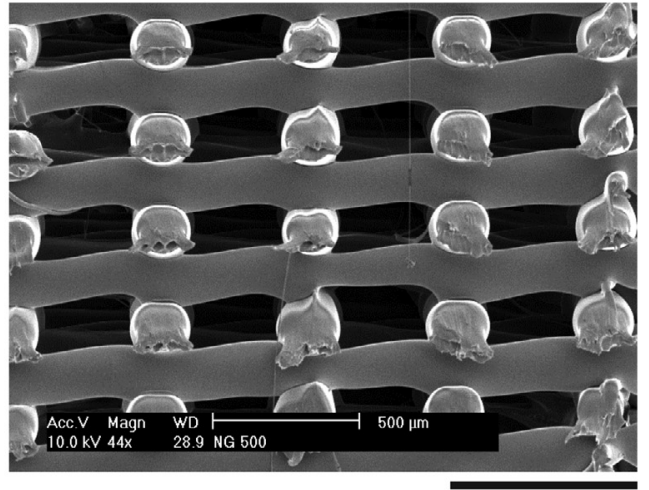

e

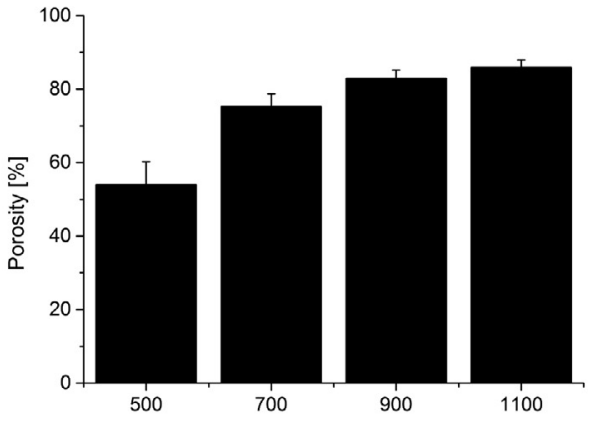

d

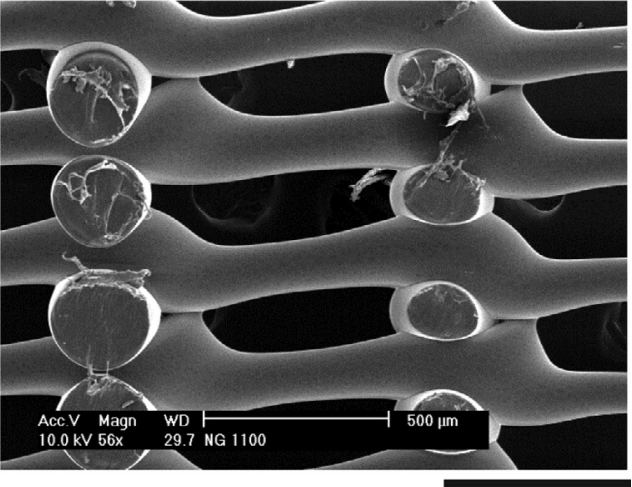

f

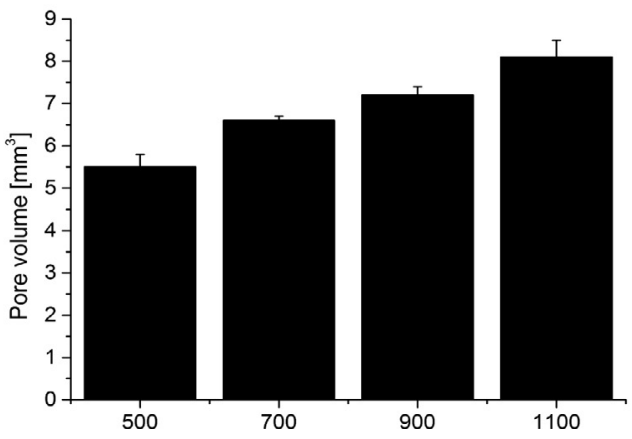

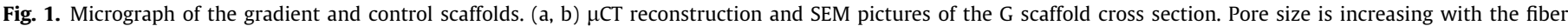

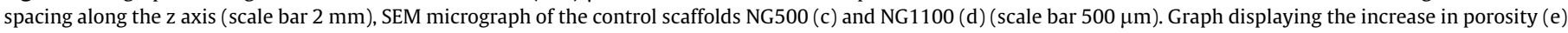
and pore volume (f) along the $\mathrm{z}$ axis in the gradient scaffold.

II showed a similar trend with a 7-fold increase when the fiber spacing was set at $500 \mu \mathrm{m}$ and a 3-fold increase with a fiber spacing of $700 \mu \mathrm{m}$. Aggrecan displayed the highest differences between the portions with a 21 - and a 4-fold increase in the $500 \mu \mathrm{m}$ and $700 \mu \mathrm{m}$ zones, respectively.

\subsubsection{Cellularity and ECM within the gradient}

After 28 days of culture, hMSCs number decreased with increasing the pore size in chondrogenic medium (Fig. 6b), while there was no difference in basic medium. GAG amount followed the same trend (Fig. 6a). The portion with the smallest pore size was filled with a GAG/DNA amount of $65.06 \pm 7.85 \mu \mathrm{g}$, which decreased to $19 \pm 2.73 \mu \mathrm{g}$ in the further porosity zone and to $7.27 \pm 2.44$ in the largest pore zone (Fig. 6a). A similar trend was seen under basic conditions where the $900 / 1100 \mu \mathrm{m}$ portion showed a significantly lower amount of GAG/DNA with respect to the $700 \mu \mathrm{m}$ and $500 \mu \mathrm{m}$ zones, which had a similar amount. The same trend and statistical significances were maintained by normalizing the amount of GAG per zone when the structural properties were taken into consider- ation (Supporting Information, Fig. S1). The cell number was the highest in the $500 \mu \mathrm{m}$ part, which displayed $87564 \pm 16218$ with respect to the $700 \mu \mathrm{m}$ and $900 / 1100 \mu \mathrm{m}$ with $57708 \pm 7470$ and $44970 \pm 7955$, respectively. To further prove our hypothesis that protein gradient formation could be correlated to differential hypoxic conditions due to different cell nutrient availability in the different scaffold regions, we also analyzed the production of hypoxia inducible factors (HIF). Our results confirmed that in the smallest pore size region a higher HIF- $1 \alpha$ and HIF- $2 \alpha$ secretion was measured. Both HIFs production decreased with increasing pore size (Supporting Information, Fig. S3).

\section{Discussion}

In the present study, scaffolds with a discrete gradient in pore size were fabricated and showed to influence hMSCs chondrogenic differentiation. The pores increased in size along the longitudinal axis by increasing the fiber spacing by $200 \mu \mathrm{m}$ every millimeter. As expected this led to an increase in porosity and pore volume. 
Table 2

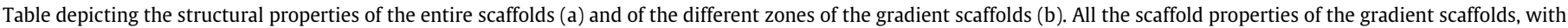

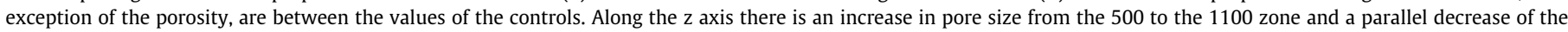
available surface.

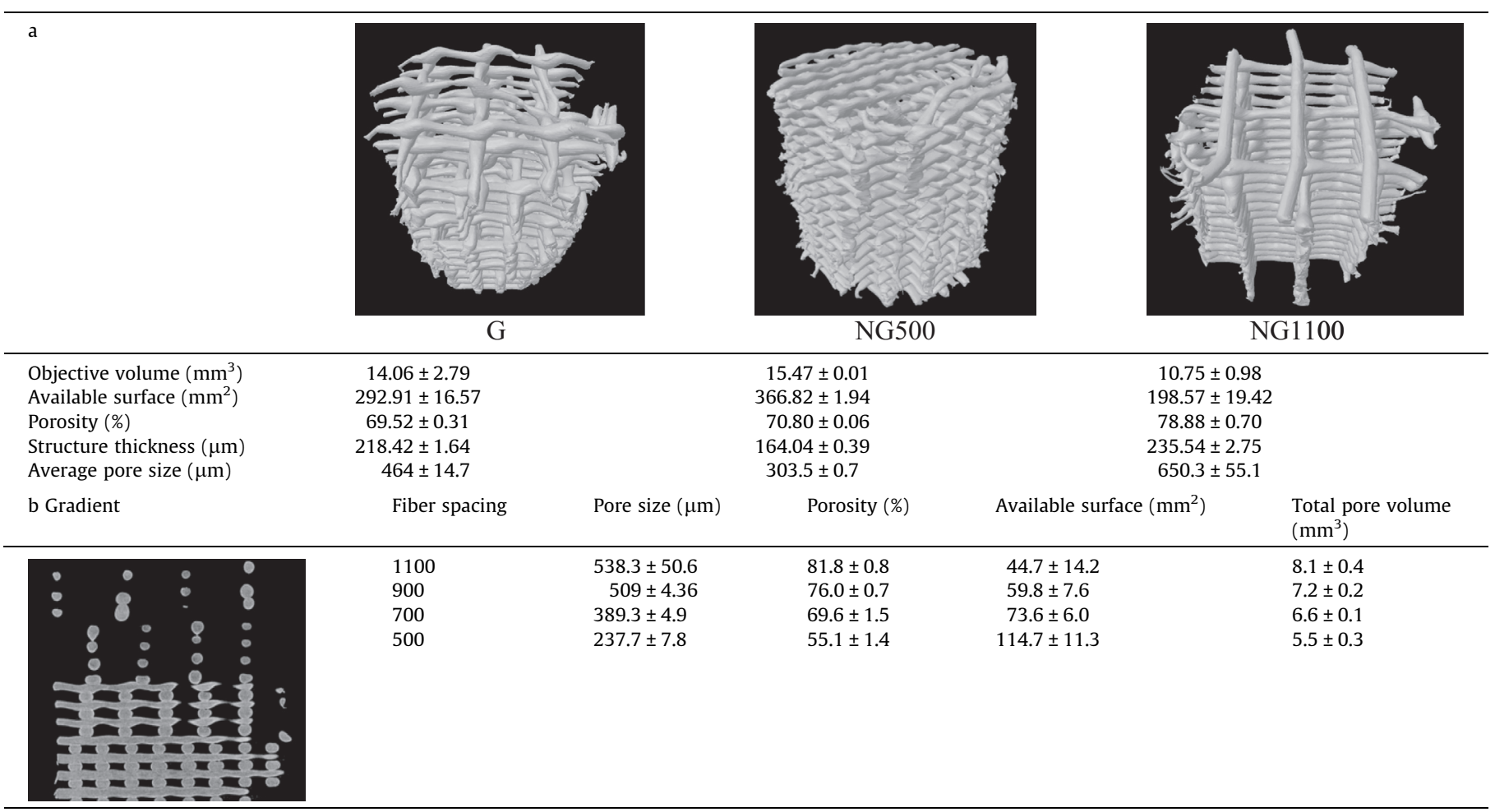
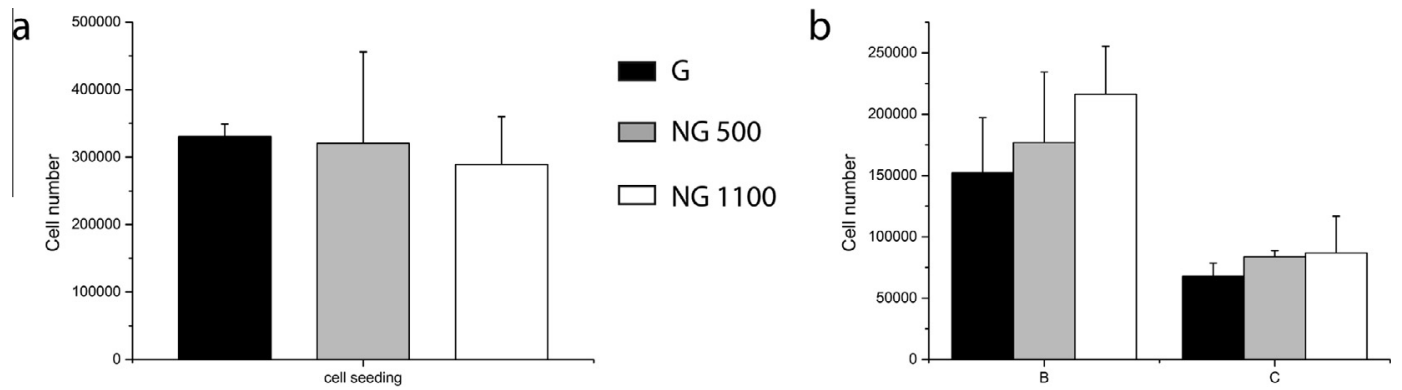

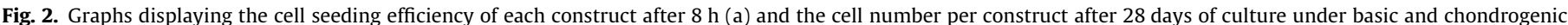
conditions (b).

Despite some fluctuations in the fiber size, especially in the gradient scaffolds where the continuous change of the contact points between subsequent layers may have contributed to a different plastic deformation of the molten polymer during extrusion, the fabricated scaffolds displayed a controlled tunable pore network architecture. A further improvement on such fluctuations could be obtained, for example, by better controlling the heating path of the molten polymer from the cartridge where it is placed to the needle where it is extruded. Limiting the time window in which the polymer is heated would result in less thermal degradation, which would consequently result in less variations due to change of molten viscosity of the material. Other additive manufacturing technologies have been also used to create gradients in pore size, such as stereolithography [31]. In this respect, the technology that we have used is not necessarily better than other additive manufacturing technologies. The novelty of our study lies in the design of the pore size gradients specifically tuned for stem cell driven articular cartilage regeneration, while other studies using additive manufactured scaffolds focused only on improvement of cell entrapment or better cartilage regeneration with primary differentiated chondrocytes.

We expected that the gradient along the $\mathrm{z}$ axis should have generated a sieve effect increasing cell adhesion due to an increased number of fiber connections. Sobral et al. [15] showed how a gradient structure can enhance the cell entrapment ability of a scaffold by increasing the fiber connections point where cell adhesion begins. Our findings are in contrast to this study, since no differences could be seen in cell number after $8 \mathrm{~h}$. Even though a sieve effect could be expected in our scaffolds, this did not affect the cell seeding with respect to the control scaffolds. Furthermore, to compensate as much as possible the effect of gravity on cell seeding distribution, scaffolds were flipped every day, which is known to improve cell homogeneous distribution in additive manufactured scaffolds [32]. The different gradient direction of the fore mentioned study and the consequent number of fibers encountered along the $\mathrm{z}$ axis by the cells could have determined a sieve effect greater than the one showed by our scaffolds. As expected, by culturing the scaffolds in basic and chondrogenic medium 


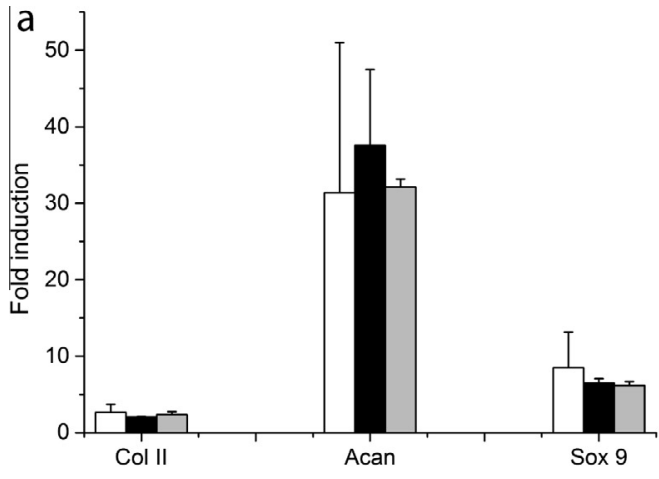

G

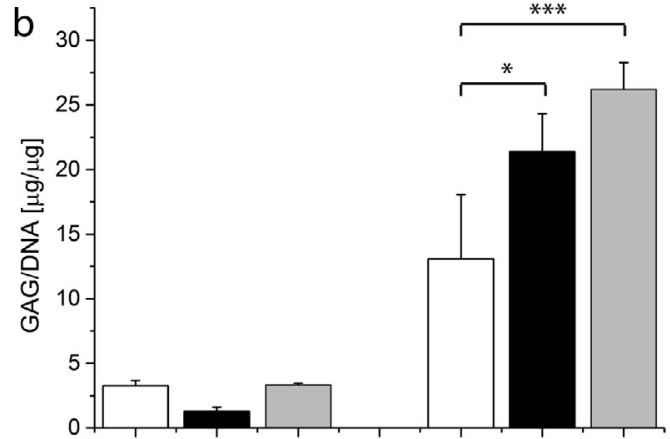

$\mathrm{NO}^{1100^{B}} \quad \mathrm{G}^{B} \mathrm{NO}^{500^{B}} \quad \mathrm{NG}^{110^{\circ}} \mathrm{O}^{\mathrm{C}} \mathrm{NO}^{\mathrm{SOO}^{\circ}}$

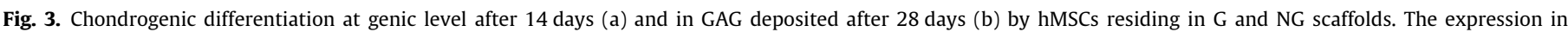

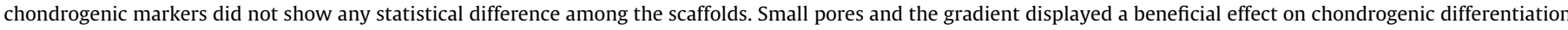

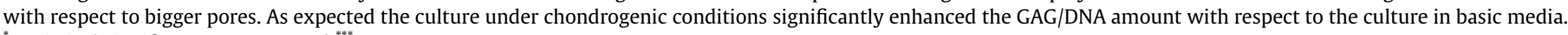
"Statistical significance $\mathrm{p}<0.05$ and ${ }^{* * *} \mathrm{p}<0.001$.

BASIC
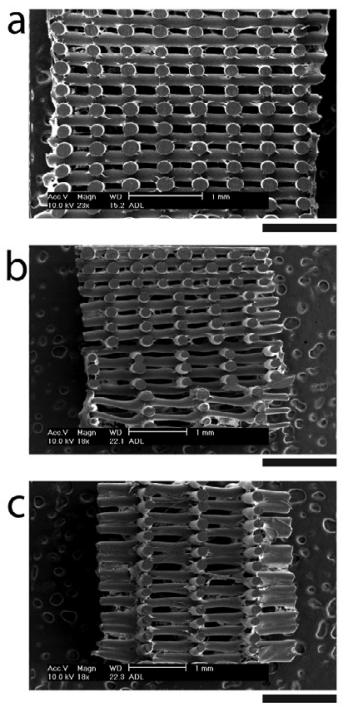

G

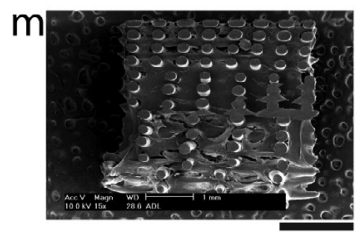

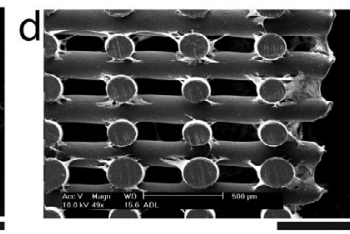
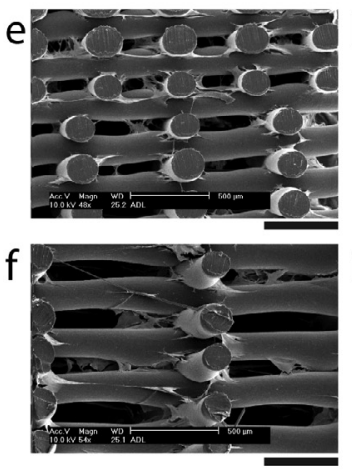

500

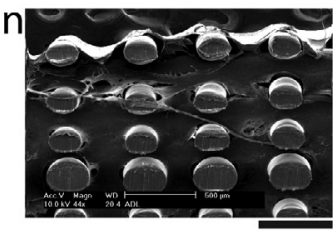

CHONDROGENIC
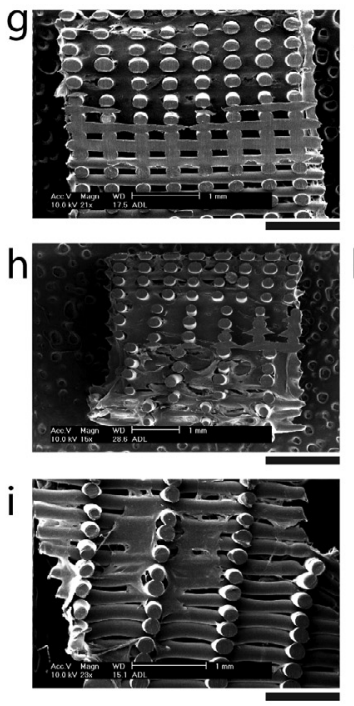

$700 / 900$

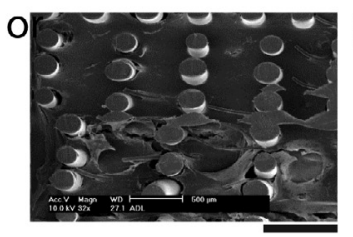

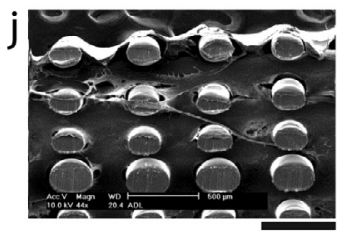
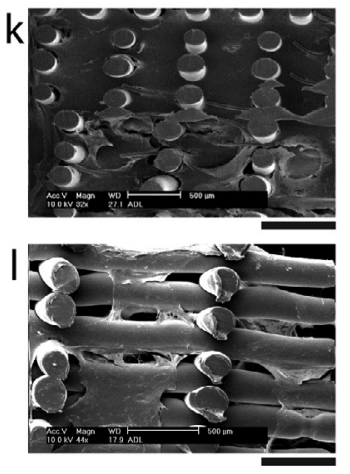

$900 / 1100$

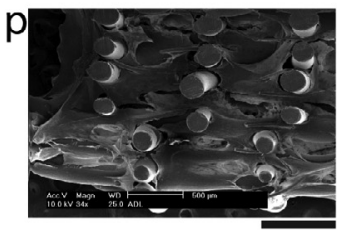

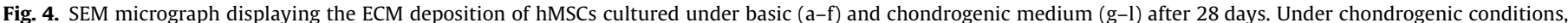

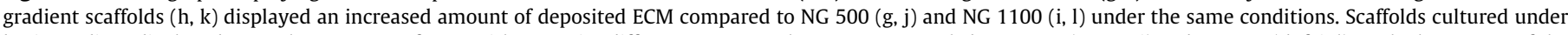

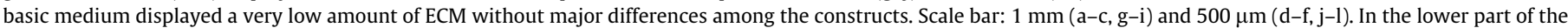

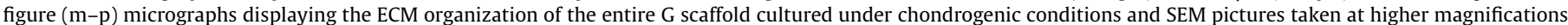
of the gradient zones. Scale bar: $1 \mathrm{~mm}(\mathrm{~m})$ and $500 \mu \mathrm{m}(\mathrm{n}-\mathrm{p})$.

a significant difference in cell number between the conditions was measured. Cell adhesion on the scaffolds is mediated by proteins such as laminin, fibronectin and vitronectin [33-35], which are commonly present in the FBS contained in the basic medium. As chondrogenic medium does not contain FBS, it is reasonable to expect a decrease in cell number with culturing time, which is also in line with the low cell density of articular cartilage tissue.
The scaffold features in terms of porosity and pore size did not affect hMSCs proliferation either. It is known that structural properties such as pore shape and size affect ECM deposition [16,36]. In particular, from the study of Woodfield et al., when cells are cultured within structures with small pores, the release of GAG is significantly enhanced with respect to structures presenting bigger pores [16]. Similarly, in our study the scaffolds presenting a 


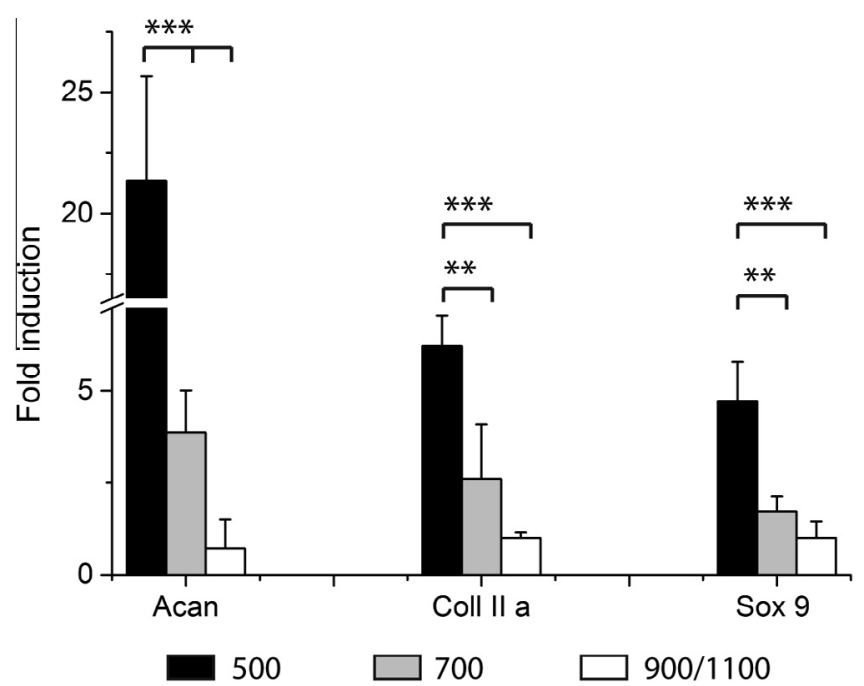

Fig. 5. Differentiation of hMSCs residing in the different compartments of the gradient scaffolds at a genetic level. The smaller pores seemed to trigger a higher expression of chondrogenic markers. All the differences between the zones were statistically significant for all the genes. Aggrecan variation was significant also between the $700 \mu \mathrm{m}$ and $900 / 1100 \mu \mathrm{m}$ fiber spacing regions. ${ }^{* *}$ Statistical significance $\mathrm{p}<0.01,{ }^{* * *} \mathrm{p}<0.001$.

homogeneous fiber spacing of $500 \mu \mathrm{m}$ showed a significantly higher amount of GAG/DNA with respect to the NG1100 scaffolds (Fig. 3b). The gradient scaffolds supported an amount of GAG/ DNA which is closer to the amount presented by the scaffolds with a homogenous pore size of $326 \mu \mathrm{m} \pm 17 \mu \mathrm{m}$ and significantly higher than the amount present in the scaffolds with a homogenous pore size of $968 \mu \mathrm{m} \pm 25 \mu \mathrm{m}$.

In vivo, chondrogenesis begins from the condensation of hMSCs after the exposure to TGF- $\beta$, which leads to the expression of molecules involved in the condensation process such as tenascin $C$, fibronectin and N-cadherin $[37,38]$. Condensation leads to the expression of the transcription factor sex determining region $\mathrm{Y}-$ box 9 (sox-9). The cells within the aggregates proceed to chondroblasts and begin to produce aggrecan and collagen type II, IX, and XI. This development is carried on by the effect of sox- 9 in combination with the influence of a growth factor cocktail, including among others insulin growth factor-1, fibroblast growth factor-2, and bone morphogenetic proteins (BMPs)-2, -4, -7, and -14 $[37,39,40]$. A study of Steinert et al. [41] showed a correlation between the size of cell aggregate, number of cells and GAG deposited. By increasing the size of the cell aggregate, the cell number and the GAG deposited also increased. In the present study, we hypothesized that the structural properties of the construct could have determined a faster filling of the smaller pores and the consequent aggregate-like state of hMSCs. This may have led to a faster and more pronounced differentiation toward the chondrogenic lineage. In the full scaffolds, the pore geometry seemed to affect only the ECM deposition and not the differentiation, since no major differences could be seen in terms of chondrogenic markers at the genic level. The ECM produced seemed to be mainly based on proteoglycans, since the synthesis of coll II mRNA was not significantly induced, whereas ACAN gene expression was enhanced in all the constructs already after 2 weeks.

A similar explanation can be proposed for the behavior of hMSCs residing in the different gradient compartments. The portion with a fiber spacing of $500 \mu \mathrm{m}$ is the one presenting the smallest pore size and the highest cell number. It is known that the initial cell density can drive the differentiation of the hMSCs $[42,43]$. The highest cell density per volume unit within the $500 \mu \mathrm{m}$ part may have led the cells to assume an aggregate like
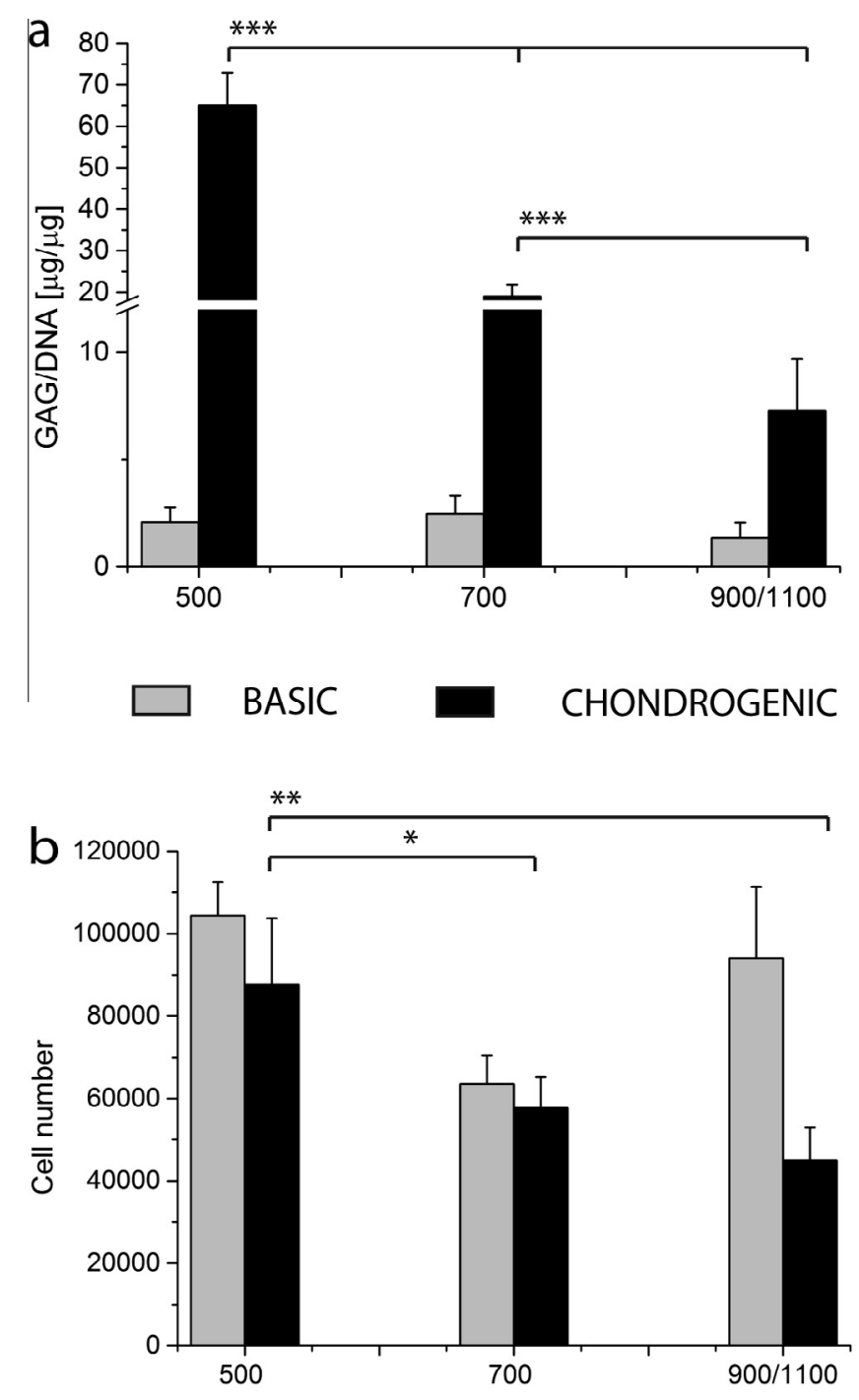

Fig. 6. GAG/DNA (a) and cell number (b) in the different compartment of the gradient scaffolds. Under chondrogenic conditions both the GAG/DNA and the cell number showed a decreasing trend from the zone with smaller pores to the zone with bigger pores. Under basic conditions no trend can be seen, the cell number was higher at the bottom and top part of the scaffolds, whereas GAG/DNA was lower in the portion with bigger pores. "Statistical significance $\mathrm{p}<0.05,{ }^{* *} \mathrm{P}<0.01$ and ${ }^{* * *} \mathrm{P}<0.001$.

state, such as the initial mesenchymal cell condensation stage of the chondrogenic differentiation. $\mathrm{N}$-cadherin mediates cell-cell interaction during cell condensation. Wnt-7a positively regulates $\mathrm{N}$-cadherin expression in that stage, and it is regulated by TGFbeta. TGF-beta is added in the differentiation medium, it activates p38 MAPK pathway inhibiting the Wnt-7a/beta-catenindependent degradation of Sox9, therefore favoring ECM deposition and chondrogenesis $[44,45]$. Bigger pores determined a delay in the activation of this process, generating a gradient in expression of chondrogenic markers opposite than the pore size increase. At the genetic level as well as at the protein level, the same trend was visible with an over expression of sox9, collagen type II and aggrecan in the small pore area compared to the $700 \mu \mathrm{m}$ and the $900 / 1100 \mu \mathrm{m}$ fiber spacing zones. In the study by Oh et al. the chondrogenic differentiation of hMSCs increased by increasing the pore size. In a PCL scaffolds with a gradient in pore size ranging from $90 \mu \mathrm{m}$ to $400 \mu \mathrm{m}$, the more favorable environment for chondrogenic differentiation was showed by the pore size ranging from 370 to $400 \mu \mathrm{m}$ after 21 days of culture [46]. Similarly, in the 
present study the highest chondrogenic differentiation was displayed by the zone with pore size of $326 \mu \mathrm{m} \pm 17 \mu \mathrm{m}$, close to the optimum presented in the fore mentioned study. A further increase in pore size depicted an inverted trend with respect to Oh's study.

The GAG deposited can be determined just by the higher cell number in one compartment with respect to another. In order to decouple the effect of cell number, normalization by DNA was performed. The amount of GAG produced within the gradient zones can be expressed as total amount of GAG measured in the $500 \mu \mathrm{m}, 700 \mu \mathrm{m}$ and 900/1100 $\mu \mathrm{m}$ zones. Therefore, normalization by pore volume unit was also performed. Independently from cell density and pore volume, the gradient zone with the smallest pore always resulted with the greater amount of produced GAG. The increased cell density in the $500 \mu \mathrm{m}$ zone and the lower pore size may result in a decreased oxygen tension and nutrient availability. In literature several papers correlated the oxygen tension and chondrogenesis [47-49]. Recently, Lee et al. [50] showed the correlation between the survival pathway phosphatidylinositol 3-kinase (PI3K)/Akt/FoxO pathway, activated by hypoxia, and the increased chondrogenic differentiation of hMSCs. The low oxygen tension determines a cytosolic accumulation of hypoxia inducible factor 1 (HIF-1) and its consequent translocation in the nucleus where it acts as transcription factor. The full underlying mechanism remains still unclear [50]. Exposure to hypoxic conditions activates the PI3K/Akt pathway, involved in terminal chondrocyte differentiation, promotes chondrocytes proliferation and inhibits their hypertrophic differentiation. The enhanced chondrogenic differentiation in the small pore compartment can be based on the generation of a hypoxic environment due to the cell density and pore size. This was further supported by the analysis of HIF- $1 \alpha$ and HIF- $2 \alpha$, which both increased with decreasing pore size in our scaffolds (Supporting Information, Fig. S3).

Articular cartilage presents gradients in cell number, oxygen and nutrient availability and ECM components which follow different directions [1]. In particular, the top part of the scaffolds showed the highest cell number which is decreasing with the increasing in pore size. This would suggest the use of the small pores as superficial layer and the $900 / 1100 \mu \mathrm{m}$ portion as deep zone. In native articular cartilage the GAG amount increases when moving from the deep to the superficial layer. Also the nutrient availability and oxygen tension decrease from the superficial zone moving to the deep zone. According to our findings the $500 \mu \mathrm{m}$ fiber spacing zone, corresponding to a pore size of $\sim 300 \mu \mathrm{m}$, is the one showing the highest expression in chondrogenic markers, in terms of glycosaminoglycans synthesis, as well as HIF secretion. Despite Oh's study showed that below $300 \mu \mathrm{m}$ in pore size chondrogenesis is not improved, we could not exclude that by further decreasing the pore size below $300 \mu \mathrm{m}$ a further increase in chondrogenic differentiation could have been observed with our scaffolds as they display a completely interconnected pore network. Further studies could look into such smaller pore size, taking into account that with this technique the pore size limitation is dictated by the fiber dimension and reaches a resolution limit of approximately $100 \mu \mathrm{m}$. Further studies will be aimed at identifying more components of the ECM in the different zones. Presence and structure of collagen type II fibrils can be markers to correlate the structure of the native cartilage with the one formed within the scaffold. Additionally, an analysis on the expression of collagen X may clarify if the state of hypertrophic cartilage is reached and may contribute deciding which direction to choose for the implantation of the gradient scaffold in an in vivo model. Supplementary studies are still needed to understand if the hMSCs within a porosity gradient are able to reach the state of mature cartilage and if the gradients found in the native cartilage are formed in vivo. A further application could be the use of such scaffolds for osteochondral regeneration, where the small pores are indeed used for chondrogenesis, while the larger pores are used for osteogenesis. In this respect, we have conducted additional studies on the influence of such gradient scaffolds on the osteogenic differentiation of MSCs and found out that with increasing pore size osteogenic differentiation was enhanced [51]. Nonetheless, fabricating scaffolds with structural gradients seems a promising approach to support a hierarchical chondrogenic differentiation of adult stem cells.

\section{Conclusions}

Articular cartilage can be seen as a gradient tissue. Therefore, the use of gradient scaffolds in combination with undifferentiated cells can be foreseen as tools for its regeneration. In the present study, a scaffold presenting a gradient in porosity was successfully produced and the differentiation of hMSCs showed enhanced chondrogenic gene expression and an increased GAG deposition with decreasing the pore size, likely due to a related higher cell density and the consequent generation of hypoxic conditions. The cells growing within the gradient scaffolds seemed to support a higher ECM deposition in comparison with the NG scaffolds. The same trend was observed among the gradient zones. Structural gradients could, thus, be considered as a promising strategy for the design of scaffolds aiding to the process of adult stem cell chondrogenic differentiation.

\section{Acknowledgements}

This research was financially supported by the Dutch Technology Foundation STW (STW, 11135) and by the Province of Limburg.

\section{Appendix A. Supplementary data}

Supplementary data associated with this article can be found, in the online version, at http://dx.doi.org/10.1016/j.actbio.2016.03. 014.

\section{References}

[1] A. Di Luca, C.A. Van Blitterswijk, L. Moroni, The osteochondral interface as a gradient tissue: from development to the fabrication of gradient scaffolds for regenerative medicine, Birth Defects Res. C, Embryo Today: Rev. 105 (2015) 34-52.

[2] A.M. Bhosale, J.B. Richardson, Articular cartilage: structure, injuries and review of management, Brit. Med. Bull. 87 (2008) 77-95.

[3] Y. Na, H. Oh, Y. Ahn, Y. Han, Suturing property of tough double network hydrogels for bio-repair materials, Korea-Aust. Rheol. J. 27 (2015) 25-31.

[4] M.A. Oberlander, C.L. Baker, B.E. Morgan, Patellofemoral arthrosis: the treatment options, Am. J. Orthop. (Belle Mead NJ) 27 (1998) 263-270.

[5] J.R. Steadman, W.G. Rodkey, J.J. Rodrigo, Microfracture: surgical technique and rehabilitation to treat chondral defects, Clin. Orthop. Relat. Res. 391 (2001) S362-S369.

[6] S. Wakitani, K. Imoto, T. Yamamoto, M. Saito, N. Murata, M. Yoneda, Human autologous culture expanded bone marrow mesenchymal cell transplantation for repair of cartilage defects in osteoarthritic knees, Osteoarthritis Cartilage 10 (2002) 199-206.

[7] B. Johnstone, J.U. Yoo, Autologous mesenchymal progenitor cells in articular cartilage repair, Clin. Orthop. Relat. Res. 367 (1999) S156-S162.

[8] E.B. Hunziker, Articular cartilage repair: are the intrinsic biological constraints undermining this process insuperable?, Osteoarthritis Cartilage 7 (1999) 1528

[9] R. Gudas, R.J. Kalesinskas, V. Kimtys, E. Stankevicius, V. Toliusis, G. Bernotavicius, A. Smailys, A prospective randomized clinical study of mosaic osteochondral autologous transplantation versus microfracture for the treatment of osteochondral defects in the knee joint in young athletes, Arthroscopy 21 (2005) 1066-1075.

[10] M.T. Ghazavi, K.P. Pritzker, A.M. Davis, A.E. Gross, Fresh osteochondral allografts for post-traumatic osteochondral defects of the knee, J. Bone Joint Surg. Brit. 79-B (1997) 1008-1013.

[11] T.J. Levingstone, A. Matsiko, G.R. Dickson, F.J. O’Brien, J.P. Gleeson, A biomimetic multi-layered collagen-based scaffold for osteochondral repair, Acta Biomater. 10 (2014) 1996-2004.

[12] S.W. Suh, J.Y. Shin, J. Kim, J. Kim, C.H. Beak, D.I. Kim, H. Kim, S.S. Jeon, I.W. Choo, Effect of different particles on cell proliferation in polymer scaffolds using a 
solvent-casting and particulate leaching technique, ASAIO J. 48 (2002) 460464.

[13] D. Sin, X. Miao, G. Liu, F. Wei, G. Chadwick, C. Yan, T. Friis, Polyurethane (PU) scaffolds prepared by solvent casting/particulate leaching (SCPL) combined with centrifugation, Mater. Sci. Eng. C 30 (2010) 78-85.

[14] D. Leatrese, B.-S.K. Harris, David J. Mooney, Open pore biodegradable matrices formed with gas foaming, J. Biomed. Mater. Res. 42 (3) (1998) 396-402.

[15] J.M. Sobral, S.G. Caridade, R.A. Sousa, J.F. Mano, R.L. Reis, Three-dimensional plotted scaffolds with controlled pore size gradients: effect of scaffold geometry on mechanical performance and cell seeding efficiency, Acta Biomater. 7 (2011) 1009-1018.

[16] T.B.F. Woodfield, C.A. Van Blitterswijk, J. de Wijn, T.J. Sims, A.P. Hollander, J. Riesle, Polymer scaffolds fabricated with pore-size gradients as a model for studying the zonal organization within tissue-engineered cartilage constructs Tissue Eng. 11 (9-10) (2005) 1297-1311.

[17] J.C. Leijten, J. Emons, C. Sticht, S. van Gool, E. Decker, A. Uitterlinden, G. Rappold, A. Hofman, F. Rivadeneira, S. Scherjon, J.M. Wit, J. van Meurs, C.A. van Blitterswijk, M. Karperien, Gremlin 1, frizzled-related protein, and Dkk-1 are key regulators of human articular cartilage homeostasis, Arthritis Rheum. 64 (2012) 3302-3312.

[18] JM. Mansour, Kinesiology: The Mechanics and Pathomechanics of Human Movement, Biomechanics of Cartilage, 2003. Chapter 5.

[19] P.L. Mente, J.L. Lewis, Elastic modulus of calcified cartilage is an order of magnitude less than that of subchondral bone, J. Orthop. Res. 12 (1994) 637647.

[20] B. Rolauffs, C. Muehleman, J. Li, B. Kurz, K.E. Kuettner, E. Frank, A.J. Grodzinsky, Vulnerability of the superficial zone of immature articular cartilage to compressive injury, Arthritis Rheum. 62 (2010) 3016-3027.

[21] A.J. Hayes, S. MacPherson, H. Morrison, G. Dowthwaite, C.W. Archer, The development of articular cartilage: evidence for an appositional growth mechanism, Anat. Embryol. 203 (2001) 469-479.

[22] C.A. van Blitterswijk, Tissue Engineering, Elsevier/Academic Press, Amsterdam; Boston, 2008.

[23] V.C. Mow, A. Ratcliffe, A.R. Poole, Cartilage and diarthrodial joints as paradigms for hierarchical materials and structures, Biomaterials 13 (1992) 67-97.

[24] Y.X. Preeti Malladi, M. Chiou, A.J. Giaccia, M.T. Longaker, Effect of reduced oxygen tension on chondrogenesis and osteogenesis in adipose-derived mesenchymal cells, Am. J. Physiol. Cell Physiol. 290 (2006) 1139-1146.

[25] N. Zhou, N. Hu, J.Y. Liao, L.B. Lin, C. Zhao, W.K. Si, Z. Yang, S.X. Yi, T.X. Fan, W Bao, X. Liang, X. Wei, H. Chen, C. Chen, Q. Chen, X. Lin, W. Huang, HIF-1 $\alpha$ as a regulator of BMP2-induced chondrogenic differentiation, osteogenic differentiation and endochondral ossification in stem cells, Cell. Physiol. Biochem. 36 (2015) 44-60.

[26] R.J. Deans, A.B. Moseley, Mesenchymal stem cells: biology and potential clinical uses, Exp. Hematol. 28 (2000) 875-884.

[27] F.P. Barry, J.M. Murphy, Mesenchymal stem cells: clinical applications and biological characterization, Int. J. Biochem. Cell Biol. 36 (2004) 568-584.

[28] P.J. Emans, E.J. Jansen, D. van Iersel, T.J. Welting, T.B. Woodfield, S.K. Bulstra, J. Riesle, L.W. van Rhijn, R. Kuijer, Tissue-engineered constructs: the effect of scaffold architecture in osteochondral repair, J. Tissue Eng. Regen. Med. 7 (2013) 751-756.

[29] M.B. Claase, D.W. Grijpma, S.C. Mendes, J.D. de Bruijn, J. Feijen, Porous PEOT/PBT scaffolds for bone tissue engineering: preparation, characterization, and in vitro bone marrow cell culturing, J. Biomed. Mater. Res. A 64A (2003) 291-300.

[30] L. Moroni, J.R. de Wijn, C.A. van Blitterswijk, Three-dimensional fiberdeposited PEOT/PBT copolymer scaffolds for tissue engineering: influence of porosity, molecular network mesh size, and swelling in aqueous media on dynamic mechanical properties, J. Biomed. Mater. Res. A 75 (2005) 957-965.

[31] F.P. Melchels, B. Tonnarelli, A.L. Olivares, I. Martin, D. Lacroix, J. Feijen, D.J. Wendt, D.W. Grijpma, The influence of the scaffold design on the distribution of adhering cells after perfusion cell seeding, Biomaterials 32 (2011) 28782884.

[32] A.M. Leferink, W.J. Hendrikson, J. Rouwkema, M. Karperien, C.A. van Blitterswijk, L. Moroni, Increased cell seeding efficiency in bioplotted threedimensional PEOT/PBT scaffolds, J. Tissue Eng. Regen. Med. (2013).
[33] J. Wei, T. Igarashi, N. Okumori, T. Igarashi, T. Maetani, B. Liu, M. Yoshinari, Influence of surface wettability on competitive protein adsorption and initial attachment of osteoblasts, Biomed. Mater. 4 (2009) 045002.

[34] E. Ruoslahti, M. Pierschbacher, New perspectives in cell adhesion: RGD and integrins, Science 238 (1987) 491-497.

[35] R. Pytela, M.D. Pierschbacher, E. Ruoslahti, A 125/115-kDa cell surface receptor specific for vitronectin interacts with the arginine-glycine-aspartic acid adhesion sequence derived from fibronectin, Proc. Natl. Acad. Sci. U.S.A. 82 (1985) 5766-5770.

[36] C.M. Bidan, K.P. Kommareddy, M. Rumpler, P. Kollmannsberger, P. Fratzl, J.W. Dunlop, Geometry as a factor for tissue growth: towards shape optimization of tissue engineering scaffolds, Adv. Healthc. Mater. 2 (2013) 186-194.

[37] H.M. Kronenberg, Developmental regulation of the growth plate, Nature 423 (2003) 332-336.

[38] J. Chimal-Monroy, L. Diaz de Leon, Expression of N-cadherin, N-CAM, fibronectin and tenascin is stimulated by TGF-beta1, beta2, beta3 and beta5 during the formation of precartilage condensations, Int. J. Dev. Biol. 43 (1999) 59-67.

[39] R. Pogue, K. Lyons, BMP signaling in the cartilage growth plate, Curr. Top. Dev. Biol. 76 (2006) 1-48.

[40] Y. Wang, Z. Cheng, H.Z. Elalieh, E. Nakamura, M.T. Nguyen, S. Mackem, T.L. Clemens, D.D. Bikle, W. Chang, IGF-1R signaling in chondrocytes modulates growth plate development by interacting with the PTHrP/Ihh pathway, J. Bone Miner. Res. 26 (2011) 1437-1446.

[41] A.F. Steinert, G.D. Palmer, C. Pilapil, U. Noth, C.H. Evans, S.C. Ghivizzani, Enhanced in vitro chondrogenesis of primary mesenchymal stem cells by combined gene transfer, Tissue Eng., Part A 15 (2009) 1127-1139.

[42] M.F. Pittenger, A.M. Mackay, S.C. Beck, R.K. Jaiswal, R. Douglas, J.D. Mosca, M.A. Moorman, D.W. Simonetti, S. Craig, D.R. Marshak, Multilineage potential of adult human mesenchymal stem cells, Science 284 (1999) 143-147.

[43] R. McBeath, D.M. Pirone, C.M. Nelson, K. Bhadriraju, C.S. Chen, Cell shape, cytoskeletal tension, and RhoA regulate stem cell lineage commitment, Dev. Cell. 6 (2004) 483-495.

[44] R. Tuli, S. Tuli, S. Nandi, X. Huang, P.A. Manner, W.J. Hozack, K.G. Danielson, D.J. Hall, R.S. Tuan, Transforming growth factor-beta-mediated chondrogenesis of human mesenchymal progenitor cells involves N-cadherin and mitogenactivated protein kinase and Wnt signaling cross-talk, J. Biol. Chem. 278 (2003) 41227-41236.

[45] E.J. Jin, S.Y. Lee, Y.A. Choi, J.C. Jung, O.S. Bang, S.S. Kang, BMP-2-enhanced chondrogenesis involves p38 MAPK-mediated down-regulation of Wnt-7a pathway, Mol. Cells 22 (2006) 353-359.

[46] Se Heang Oh, T.H. Kim, Gun Il Im, Jin Ho Lee, Investigation of pore size effect on chondrogenic differentiation of adipose stem cells using a pore size gradient scaffold, Biomacromolecules 11 (2010) 1948-1955.

[47] M. Hirao, N. Tamai, N. Tsumaki, H. Yoshikawa, A. Myoui, Oxygen tension regulates chondrocyte differentiation and function during endochondral ossification, J. Biol. Chem. 281 (2006) 31079-31092.

[48] T. Bornes, N. Jomha, A. Mulet-Sierra, A. Adesida, Hypoxic culture of bone marrow-derived mesenchymal stromal stem cells differentially enhances in vitro chondrogenesis within cell-seeded collagen and hyaluronic acid porous scaffolds, Stem Cell Res. Ther. 6 (2015) 84.

[49] M. Zhu, Q. Feng, L. Bian, Differential effect of hypoxia on human mesenchymal stem cell chondrogenesis and hypertrophy in hyaluronic acid hydrogels, Acta Biomater. 10 (2014) 1333-1340.

[50] H.H. Lee, C.C. Chang, M.J. Shieh, J.P. Wang, Y.T. Chen, T.H. Young, T.H. Young, S. C. Hung, Hypoxia enhances chondrogenesis and prevents terminal differentiation through PI3K/Akt/FoxO dependent anti-apoptotic effect, Sci. Rep. 3 (2013) 2683.

[51] A. Di Luca, I. Lorenzo-Moldero, B. Ostrowska, A. Lepedda, C.A. van Blitterswijk, L. Moroni, Gradients in pore size enhance the osteogenic differentiation of human mesenchymal stromal cells in three-dimensional scaffolds, Sci. Rep. 10 (2016) 22898. 